\title{
lleocolic intussusception in a premature neonate
}

\author{
Joana Saldanha, Inês Carmo Girbal
}

Neonatology Unit, Paediatrics Department, Hospital Santa Maria, Centro Hospitalar Lisboa Norte, Lisboa, Portugal

\section{Correspondence to} Dr Joana Saldanha, joanasaldanha@sapo.pt

Accepted 5 August 2015
CrossMark

To cite: Saldanha J, Girbal IC. BMJ Case Rep Published online: [please include Day Month Year] doi:10.1136/bcr-2015211245

\section{DESCRIPTION}

Intussusception is a well-recognised condition in young children but very rare in newborns, with preterm neonates accounting for only $0.3-1.3 \%$ of all cases of intussusception. ${ }^{1}$ The aetiology is not well defined: it is possibly related to episodes of intestinal hypoperfusion, dysmotility or intestinal stenosis. Duplication cysts, Meckel's diverticuli or meconium plugs can act as a mechanical lead point, provoking the subsequent invagination. ${ }^{2}$ Clinically, it can be indistinguishable from necrotising enterocolitis (NEC), with abdominal distention, feed intolerance and haematochezia; however, it does not have the radiological signs of NEC, such as intestinal pneumatosis or gas in the portal vein. Usually, the diagnosis is made during surgery, and the evolution is related to the viability of the intestine and necessity or extent of intestinal resection. ${ }^{3}$

A 28 -week gestation female newborn, clinically well, showed sudden worsening at day 32 of life, with rapid onset of marked abdominal distension, feed intolerance and absent bowel movements. There was no haematochezia and no palpable abdominal mass. A plain X-ray of the abdomen revealed massive ileal distension. Laboratory parameters were not diagnostic. The infant was initially treated for presumed NEC. Owing to further clinical decline, the abdominal film was repeated, showing worsening ileal distension, with an apparent fixed loop in the lower right quadrant, without intestinal pneumatosis or gas in the portal vein (figure 1). She underwent urgent exploratory

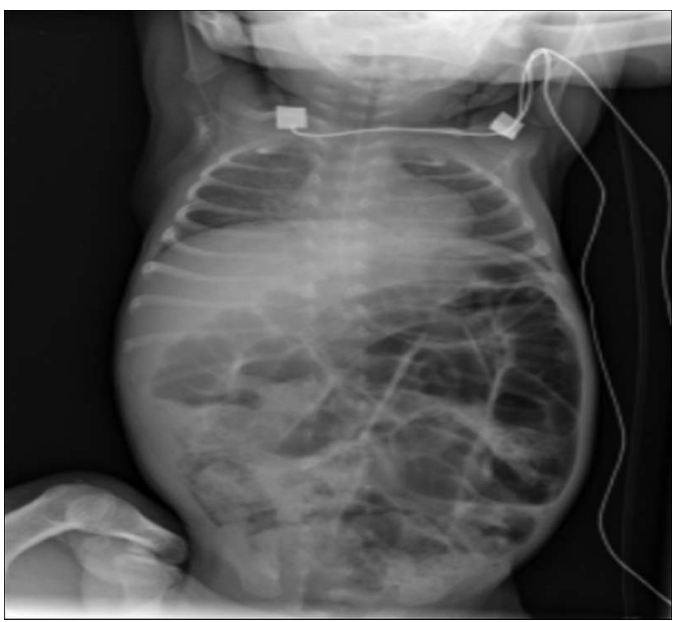

Figure 1 Abdominal X-ray with distended intestinal loops.

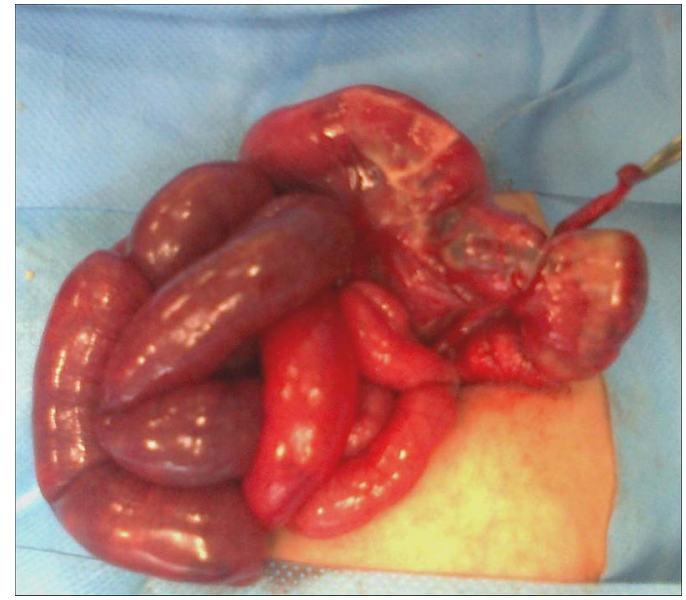

Figure 2 Bowel in surgery.

laparotomy $12 \mathrm{~h}$ after the first symptoms. An ileocecocolic intussusception (figure 2) was corrected without intestinal resection. Currently, at 4 years, the child remains clinically well.

\section{Learning points}

- Although very rare in premature neonates, intussusception should not be ruled out as a cause of an acute abdomen based on gestational age alone.

- Early diagnosis is a key element in prognosis. In stable infants, an abdominal ultrasound can be of use in establishing the diagnosis of intussusception.

Competing interests None declared.

Patient consent Obtained.

Provenance and peer review Not commissioned; externally peer reviewed.

\section{REFERENCES}

1 Avansino RJ, Bjerke S, Hendrickson M, et al. Clinical features and treatment outcome of intussusception in premature neonates. J Pediatr Surg 2003;38:1818-21.

2 Shad J, Biswas R. lleo-colic intussusceptions in a premature neonate. BMJ Case Rep 2011;2011:bcr1120115109.

3 Boubal M, Jacquot A, Baud C, et al. Acute intussusception, a rare cause of small bowel obstruction in premature neonates: the advantages of early diagnosis. Arch Pediatr 2010;17:1469-72. 
Copyright 2016 BMJ Publishing Group. All rights reserved. For permission to reuse any of this content visit http://group.bmj.com/group/rights-licensing/permissions.

BMJ Case Report Fellows may re-use this article for personal use and teaching without any further permission.

Become a Fellow of BMJ Case Reports today and you can:

- Submit as many cases as you like

- Enjoy fast sympathetic peer review and rapid publication of accepted articles

- Access all the published articles

- Re-use any of the published material for personal use and teaching without further permission

For information on Institutional Fellowships contact consortiasales@bmjgroup.com

Visit casereports.bmj.com for more articles like this and to become a Fellow 